Article

\title{
The Second-Image Reversed and Climate Policy: How International Influences Helped Changing Brazil's Positions on Climate Change
}

\section{Sjur Kasa}

Center for International Climate and Environmental Research-Oslo (CICERO), University of Oslo, PO Box 1129, Blindern, NO-0318 Oslo, Norway; E-Mail: sjur.kasa@cicero.uio.no; Tel.: +47-22-85-87-50; Fax: +47-22-85-87-51

Received: 6 November 2012; in revised form: 8 February 2013 / Accepted: 12 February 2013 / Published: 6 March 2013

\begin{abstract}
International climate policy over the last 7-8 years has been characterized by the increasing involvement of developing countries. While COP-13 at Bali marked a stronger willingness to participate in mitigation efforts in principle, there are now numerous examples of domestic programs for mitigation by this group of countries. Brazil has gone furthest among developing countries, with a substantial voluntary commitment to reduce its emissions proclaimed in 2009. The dynamics behind the change in Brazil's position are discussed, with a particular eye to the effects of international influences. In conjunction with important domestic changes, a set of interacting influences through a variety of pathways both changed preferences among important interest groups in Brazilian society towards favoring some kind of commitments and helped to change the structure of government forums and decision-making rules in a way that empowered reform-minded ministries. It is argued that this perspective, drawn from Peter Gourevitch's idea of the "second image reversed", is increasingly relevant for understanding the influence of the broad "regime complex" on climate change on politics in developing countries.
\end{abstract}

Keywords: Brazil; climate change; positions; developing countries

\section{Introduction}

Scholarship on the forces that shape climate policy in developing countries, including positions in international negotiations, is modest. The main reason for this is of course that emissions from the non-Annex 1 countries are not limited under the Kyoto Protocol. However, recent developments merit 
a closer look at the dynamics of position development among some of the major developing countries. Since COP-13 at Bali, there has been a surge of national programs aimed at limiting the growth of emissions among developing countries [1].

This is certainly linked to the stronger call for action by developing countries that came out of COP-13, but factors, like new markets for renewable energy, as well as a weakening of the North-South conflict in the wake of strong economic performance by developing countries can also have influence on position development [2]. Nevertheless, there is still a shortage of studies of to what extent and through what mechanisms these intertwined processes may influence the positions taken by developing countries in the climate negotiations. In the following, I will try to ameliorate some of this shortage by presenting a case study of the dramatic changes in Brazil's position during the period leading up to COP-15 in 2009. This is the clearest departure from the rejection of commitments that traditionally formed the core of the G77 and China position in the climate negotiations [1]. Brazil's positions were, until recently, characterized by a staunch adherence to the traditional non-commitment position of the G77. However, beginning in 2005, there was a gradual softening of the country's previous intransigent resistance against discussing emissions from deforestation in the negotiations. Nevertheless, it still came as a massive surprise when President Lula and Brazil's Minister of the Environment at that time, Carlos Minc, in November 2009 declared a voluntary commitment to implement substantial cuts in Brazilian emissions from a 2020 baseline. Such a move had been explicitly rejected by the chief negotiator from the Ministry of External Affairs, Everton Vargas, as late as 2008 [3]. The new commitment, which was codified in a law on National Climate Policy in late December 2009, also places Brazil as the most ambitious among the major developing countries when it comes to plans for domestic implementation of proclaimed climate ambitions [1]. Adding to this, there were important changes also when it comes to other aspects of Brazil's position. While Brazil had always insisted on the North's financial responsibility for mitigating emissions also in the South, in his last speech in Copenhagen, Lula abandoned this position by offering to contribute to a fund for mitigation and adaptation by developing countries.

Inspired by Gourevitch's [4] "second image reversed" approach, I will argue that a set of complex and mutually reinforcing external influences contributed to the changes that took place in Brazil's position. Emerging arrangements both within the formal UNFCCC regime and other uni- and multi-lateral initiatives, as well as developments in international markets contributed to major changes in Brazilian domestic politics on climate change and rearrangements of governmental authority structures or the organizations and rules for participation involved in determining the position [5]. The emphasis on how international factors contributed do not imply that I underestimate the importance of more purely domestic factors, although I highlight some international influences, which I think deserve more attention than what they receive in Hochstetler and Viola's [1,6] interpretations. However, the main difference between this paper and Hochstetler and Viola's [1] contribution is that I detail through what pathways international factors became important in assisting changes in Brazil's position without discounting the role taken by domestic developments. Thus, the argument follows the lines of Ragin's [7] concept of "conjunctural causation"; international factors became important in conjunction with a particular set of domestic factors, which I explicitly discuss in the conclusion.

Partly, I claim that the change in domestic politics took place because international impulses assisted changes in societal actor preferences. Landowners and agriculturalists, who traditionally 
profited from deforestation-what Sprinz and Weiss [8] call "polluter interests" - also held an intransigent position on commitments and deforestation. However, the emergence of Reduced Emissions from Deforestation and Forest Degradation (REDD) and other compensation mechanisms for avoided deforestation held the potential of rewarding these groups for protecting their forest land, thereby motivating a new preference for a more flexible Brazilian position. Likewise, the passing of the US Waxman-Markey Act on border taxes for imports from countries without commitments by the House of Representatives in June 2009 - even though later failing in the Senate - made a broad range of Brazilian industrial export interests previously less interested in the Brazilian position, aware of the risks of continued intransigency in the run-up to COP-15. This motivated a new preference for a change of the position and a series of initiatives by this group of actors. Preceding these developments, from the mid-2000s, increasing demand for Brazilian biofuels partly linked to rising international concerns for climate change helped mobilizing the rapidly expanding Brazilian bioethanol industry as a new "helper interest." This industry had a preference for a strong global climate agreement to boost international biofuels markets, a more flexible Brazilian position and to get rid of international market barriers linked to Brazil's negative reputation for deforestation.

These trends were accompanied by and reinforced by crucial changes in bureaucratic politics at the federal level, also facilitated by international influences. From 2003, the Ministry of the Environment (MMA) started engaging more strongly with Brazilian climate policy. When the United Nations Framework Convention on Climate Change (UNFCCC) negotiations started to focus on curbing emissions from deforestation from 2005, this opened a policy window for the MMA — with its superior competencies and expertise on deforestation - to push itself into the core of the bureaucratic politics of decision-making on positions in Brazil, challenging the traditional monopoly of the Ministry of External Affairs (hereafter the Itamaraty) and the Ministry of Science and Technology (hereafter, the MCT). This development was stimulated by the outcome of COP-13 at Bali, which encouraged voluntary action by developing countries. Successful moves by the MMA to increase its influence over Brazil's position compounded the effects of coalitional politics outlined above and gave a substantial contribution to the change of the Brazilian position in November 2009.

The paper falls into six parts. In the next section, I outline my theoretical approach mainly dealing with aspects of Gourevitch [4] "second image reversed" and more recent discussions of pathways through which international influences can have effect. In part three, I provide a short overview of the development of Brazilian positions in the negotiations on climate change. In section four and five, I discuss how international influences through various pathways contributed to change societal alliances and governmental structures in a way that facilitated the position shift. In the conclusion, I summarize my findings and qualify them by discussing the balance between domestic and international influences.

The paper is based on 17 interviews with important actors in the Brazilian government, environmental NGOs and business organizations during the period 2010-2011. Policy documents and newspaper stories are also important sources.

\section{Domestic Politics, Governmental Authority Structures and International Influences}

Analyses of international climate policy have typically been split between domestic level (second image) and international level (third image) analyses. However, with the emergence of broader 
set of international incentives for policy change through UNFCCC mechanisms, like Clean Development Mechanism (CDM) and REDD+ and broader incentives linking climate policy to energy and technology cooperation [9], it is clear that the domestic politics of climate change becomes increasingly linked to international developments. Thus, there are compelling arguments in favor of complementing the traditional "second image" logic of domestic interest mobilization explanations of climate policy positions by, including what Gourevitch [4] calls "second image reversed" explanations. Similar perspectives also exist in the more specialized literature on environmental regimes [10]. Bernstein and Cashore [11] likewise favor more attention to the issue of domestic influences of environmental regimes and broader international influences. Still, in spite of two decades of continuously evolving and widening international efforts to deal with climate change, attention to such perspectives has been modest [11-16].

While there are many ways of categorizing second-image reversed explanations, Krasner [5] makes a useful distinction between explanations that focus on the effects of international influences on the composition and preferences of interest groups - coalitional politics [4] - in the policy process and explanations that focus on the effects of international impulses on the governmental authority structure within which decisions are made. This means that external impulses - both those related to regulations and issues within the UNFCCC regime, bilateral actions between states and broader climate-related developments in global energy markets - may influence not only interests, but also the domestic institutional and organizational underpinnings of climate policy. This argument is particularly relevant for the study of climate policy in developing countries, as organizations and institutions in this emerging policy area are still very much in the process of being shaped.

Bernstein and Cashore [11] distinguish between international influences through four distinct pathways; namely, binding international rules, norms and discourse, markets and direct access to domestic policy-making. Impulses through these pathways may explain both changes in governmental authority structures and coalitional politics. Flexible mechanisms, like the CDM, or emerging mechanisms, like REDD, may, for example, influence both the preferences of interest groups for particular climate policies and the preferences of and division of tasks between government agencies related to climate policies. Bernstein and Cashore [11] also note a number of important "complexities"; namely, that systems of international environmental governance are often fragmented and overlapping, that the suggested pathways can be synergistic and-like Litfin [17] - that boundaries between international and domestic politics can be blurred.

For the sake of order, I still distinguish between effects of international influences through the mentioned pathways on coalitional politics and governmental authority structures. In real life, these certainly interact. However, it may also be useful to see them as analytically distinct, as the effects of changes in coalitional politics on climate policy — in the following international positions - may be blocked by intransigency linked to organizational and institutional inertia in the bureaucracy.

For describing effects of international impulses on coalitional politics, I use Sprinz and Weiss' [8] distinction between victim interests, polluter interests and helper interests. Victim interests are groups negatively affected by climate change (including environmental NGOs), polluter interests are interest groups involved in emission intensive activities and third-party or helper interest are those interest groups who are involved in economic activities that may help reducing emissions. 
However, as mentioned, we know that changes in preferences among domestic societal groups can be of little impact if governmental structures thwart their access to decision-making. Therefore, it is also relevant to study how international pressures can contribute to changes in the domestic authority structure related to the shaping of international positions. In practical terms, such influences can be channeled through all the four pathways suggested by Bernstein and Cashore [11] and can affect both the distribution of roles in climate policy between domestic agencies and bureaucratic politics by empowering certain government agencies at the expense of other. In the following, I will focus on how developments within the UNFCCC negotiations (the introduction of REDD on the negotiation agenda and the call for domestic action in the wake of COP-13 at Bali) provided the Ministry of Environment an opening for taking a new role in climate policy, which was exploited as a platform to gain influence on decision-making over the Brazilian position.

\section{The Evolution of Brazil's Position}

From the outset, the Brazilian climate policy position was largely consistent with the traditional G77 and China position. This position consists of two core elements [9]. First, there is an insistence that mitigation is the responsibility of the developed countries and that the developing countries should be permitted to deal with poverty before dealing with mitigation. Second, there is a demand for additional technological and financial resources to deal with mitigation and adaptation.

Brazil's rejection of commitments was particularly pronounced when the world started focusing on deforestation in the Amazon region as a source of greenhouse gas emissions in the late 1980s [18]. Under the semi-democratic government of President Jose Sarney (1985-1990), military worries over foreign intrusion into the Amazon region, skepticism to cooperation with the North in the Itamaraty, and pressures from regional commercial (mining, agriculture) elites in the Amazon motivated a forceful rejection of commitments by Brazil [18,19] Though there was a partial change of policies aimed at limiting Amazonian deforestation as early as 1989 [20], these did not translate into any marked change of position.

The short-lived Collor government (1990-1992) denoted a departure from this hardline, nationalist position. Collor saw a softening of the country's position on Amazonia and climate change as a precondition for his planned opening of the Brazilian economy to foreign trade and investment [20].

After Collor, there was not a complete return to the previous hardline position. A softening of the Brazilian rhetoric on climate change took place under Fernando Henrique Cardoso's (1995-2003) presidency, which was marked by stronger presidential influence over foreign policy and the development of a more positive engagement with the North and global economic institutions [1,21]. Still, there were no major changes of Brazil's position. Persson and Azar [22] note that all Brazil's submissions to the UNFCCC from COP-1 in 1994 until the early 2000s revolved around four topics of which the three first ones are congruent with the basic G77 position [9]. First, the Brazilian delegation accepted the climate problem as real and recognized the need for action. Second, the developed countries would have to act first in line with the "common, but differentiated responsibilities" recognized in the UNFCCC. Third, the need for technology transfer and financial aid to developing countries was emphasized. And fourth, Brazil used to emphasize that the country already had some domestic achievements in limiting emissions growth, deflecting the view that developing countries are 
doing nothing. In addition, a rejection of taking the large emissions from Amazonian deforestation into the negotiations was a permanent characteristic of the Brazilian position until well into the 2000s [1].

The three first positions were also embodied in the "Brazilian" proposal, submitted at the seventh meeting of the Ad-Hoc Working Group on the Berlin Mandate in May 1997 and subsequently refined [23]. In its essence, this is a more refined version of the Brazilian interpretation of the principle of "common, but differentiated responsibilities", suggesting that historical contributions to climate change should form the basis for commitments. As Johnson [23] notes, while offering a little more flexibility than Brazil's original position, the proposal would still—at least at the time proposed-lead to a delay of commitments long into the future for developing countries.

Brazil's high level of activity in the negotiations is illustrated by the fact that the country was heavily involved in proposing and shaping the Clean Development Mechanism that came out of the Kyoto negotiations. Here, the Brazilian delegation departed from its G77 alignment both through its close cooperation with the US over a mechanism that could involve the developing countries and agreement with the US on the inclusion of all six major greenhouse gases in the Kyoto agreement [23]. Still, there was no change of the position on developing country commitments and Brazil joined up with a set of other actors who succeeded in avoiding the inclusion of carbon offsets linked to deforestation in the CDM [24].

The issue of land-use change and CDM re-emerged at COP-9 in Milan. Here, a group of Brazilian and US NGO staff and researchers presented the idea of integrating a mechanism for credits to compensate for "avoided deforestation" into a climate agreement [25]. While being officially rejected by the Brazilian delegation, one of the presenters recall that that the head of the Brazilian delegation, executive secretary of MMA Claudio Langone, deviated from the official line by calling the proposal "interesting" [26].

The next notable change in the Brazilian position was a response to the momentum gained by the idea of "compensated deforestation" and the establishment of the Coalition for Rainforest Nations in March 2005. In a workshop under the Dialogue on Long-Term Cooperation Action to Address Climate Change by Enhancing Implementation of the Convention during COP-12 in Nairobi in 2006, Brazil proposed a funds-based solution for encouraging reduced deforestation. On the one hand, this represented the first opening to bringing tropical deforestation into the negotiations by Brazil. However, a rejection of integrating reduced deforestation into carbon markets and an emphasis by Brazil and South Africa that their proposals were meant to promote stronger action by developing countries under their existing Convention commitments rather than to suggest new commitments indicated the limits of change [27]. Nevertheless, the new position permitted the establishment of the Amazon Fund in 2008 through which Norway donated up to a billion USD as a potential reward for deforestation decreases until 2015. This marked a substantial step forward in allowing international collaboration over measures to decrease deforestation in the Amazon region.

At COP-13 at Bali, Brazil gave active support to the Bali Road Map, which opens for more active "voluntary" mitigation efforts by developing countries and the establishment of negotiations on REDD as part of the climate negotiations. However, there were more significant changes in the Brazilian position at COP-14 in Poznan. In the context of a declining deforestation rate, Brazil pledged to reduce its deforestation rate further, meaning that the country would cut it in half (from a 1996-2005 baseline) by 2018 . This promise came together with a traditional Brazilian request to recognize the efforts by 
developing countries and a continued denial to include avoided deforestation in carbon markets. The deforestation target published in Poznan was part of a domestic climate plan launched in 2008, demonstrating the emergence of broader domestic activity on climate issues by the Brazilian government. The changes of the position in Poznan indicated that Brazil had moved quite far from the hardline nationalism of the early 1990s. Nevertheless, Brazil's chief negotiator, Everton Vargas, still insisted on a rejection of commitments by Brazil and promoted the view that the North-South conflict still formed the basis of Brazil's involvement in the UNFCCC process [3].

That notwithstanding, as noted above, 2009 was marked by even more substantial changes in Brazil's position. MMA staff in favor of a more flexible Brazilian position note that the G8 meeting in L'Aquila in July 2009 denoted an important change, as Brazil and the other big developing countries (Brazil, China, South Africa, Mexico, India) agreed with the G8 economies to contribute to limit global warming to two degrees [28]. Following these developments, a series of interministerial meetings on the Brazilian position in October and November in which President Lula participated, ended with the famous declaration on the 13th of November that Brazil should cut its emissions in 2020 by between 36.1 and 38.9 percent based on a negotiated baseline. Moreover, in the following meeting in Copenhagen, in his last speech, Lula opened for the possibility that Brazil could contribute to climate funding among the least developed countries. In late December, the voluntary commitments were accepted by the Brazilian Congress as the National Climate Policy (PNMC), including the cuts agreed upon in the November meetings (the law was "regularized", a move necessary for its implementation, in October 2010). Three vetoes from President Lula against the original text that among other things called for the "gradual abandonment" of fossil fuels motivated by a concern for Brazil's rapidly expanding oil industry, does not preclude that the new position marked a clear departure from Brazil's traditional positions and a very progressive move, as compared to both India's and China's positions at the otherwise rather unsuccessful COP-15 [29]. However, it should also be noted that Brazil refrained from taking the position that other developing countries should follow its lead and adopt commitments. In this respect, Brazil's position was ambiguous with a split between its own promises and its demands for action by other developing countries [29].

I now move on discussing how various impulses from the international environment contributed to this marked shift in Brazil's position on commitments.

\section{How Market Developments Changed the Coalitional Politics on Climate Change in Brazil}

The traditional set-up of domestic societal interests behind the intransigency of the Brazilian position on commitments was linked to a powerful coalition of polluter interests, again linked to Amazonian deforestation. The major element of this coalition was regional ranching and agricultural interests. These interests were involved the acquisition and clearing of forest land for herd expansion, crop production, land speculation and logging [30]. At the same time, there were traditionally no strong business interests with a preference for a more flexible position. In the following, I will argue that the prospect of new markets for carbon offsets related to REDD (Reduced Emissions from Deforestation and Forest Degradation), expanding climate-policy related markets for Brazil's biofuel producers and the threat of border taxes by the United States both changed the preferences of established Amazonian business interests towards becoming more positive to commitments and 
recruited new business interests with broadly similar preferences as active participants in Brazilian climate policy.

\subsection{Producers in the Amazon: From Polluter to Helper Interests through Market Influences}

While ranching expansion fuelled by regional markets and land speculation were the traditional activities responsible for deforestation in the Amazon region in Brazil, there was strong growth of export oriented soya production in the region from the late 1990s mainly driven by soaring demand in the Chinese market. At the same time, exports of beef also gained importance [31]. With the Brazilian soya boom centered on the Amazonian state of Mato Grosso, serious international concern emerged over the effects of soya on deforestation, concerns fueled by Brazilian NGOs like Greenpeace [32] and Brazilian and international scientists [30].

These protests led to a reconsideration of business strategies by some of the mayor soya interests. Blairo Maggi, leader of the world's biggest soya producer, Grupo Maggi, symbolizes this reorientation. When assuming office as governor of the state of Mato Grosso (the state, which, together with Pará, produces the bulk of deforestation) in 2003, he appeared to reject any environmental constraints on soya expansion [30]. However, facing growing concern over the increasingly well-known links between deforestation and Brazilian soya in international markets, Maggi realized that the soya industry would have to behave more responsibly if it should be able to maintain its access to global markets. Thus, the major soya producers in Brazil bowed in to pressure and agreed on a "soya moratorium" in 2006 in which the two biggest soya grower and exporter associations on behalf of their members rejected buying soya from producers clearing forest land [33]. This only helped to reduce deforestation indirectly, as the main contribution of soya planting to deforestation mainly goes through pressing less profitable ranching into forest land and spurring access to the frontier through the construction of roads and other infrastructure [34]. Nevertheless, although Maggi remains a controversial figure when it comes to efforts to curb deforestation, the soya moratorium was signaled that some of the most important polluter interests were willing to reconsider their business strategies.

In the same period, the idea of "compensated deforestation" gained support internationally. REDD (Reduced Emissions from Deforestation and Degradation) became an important part of the UNFCCC negotiations after the formation of the Coalition for Rainforest Nations in 2005. In Brazil, it became increasingly clear that REDD could become a profitable opportunity for Amazonian agricultural producers and landowners, who were already frustrated by the traditional Brazilian resistance against extending the CDM mechanism to also include projects aimed at avoiding deforestation [34].

As these interests started mobilizing, a key gathering took place in Mato Grosso in early 2009. This was the meeting on "Avoiding Deforestation in the Amazon through PES Markets" as part of the international Katoomba process on Payment for Ecosystems Services initiated by the mixed forest industry/environmentalist/donor organization "Forest Trends" as early as 1999. Here, governors from various Amazonian states participated together with top politicians and staff from the MMA, Brazilian NGOs and business representatives [35]. The fact that both Carlos Minc (at that time Minister for the Environment) and Izabella Teixeira (Executive Secretary of MMA) participated in this meeting alongside (international and national) NGOs, potential foreign investors and regional business interests 
illustrates both the complex international-domestic dynamics behind the rise of REDD-related issues as a driver for Brazilian climate policy and also to what extent coalitional politics were integrated with the push for a changed position by the MMA.

Mounting Amazonian interest in the new business opportunities connected to REDD translated into a formal request for changes of the Brazilian position during a meeting of Amazon governors in Tocantins in late June 2009. In this meeting, the Amazon states urged the Brazilian government to change its denial to involve avoided deforestation in carbon markets and established a taskforce to prepare a report on REDD in the Amazon and climate policy [36]. The leader of the task force was Virigilio Viana, head of the Manaus-based forest NGO FAS (Fundação Amazonas Sustentável), which again was a key channel for several international initiatives that offered financing for forest projects in the Amazon. This illustrates one the main points of Litfin [17] and Bernstein and Cashore, [11]; namely, that the traditional international/domestic divide tends to become increasingly blurred in environmental politics, due to the internationalized character of both actors and processes.

The mobilization of Amazonian interests was also facilitated by a more purely domestic achievement highlighted by Hochstetler and Viola [1]; namely, the increasing ability of the MMA to implement programs that actually reduced deforestation from 2005. While action against deforestation was traditionally perceived as contrary to the interests of regional business elites, the fact that profits in Amazonian agribusiness actually soared in parallel with declining deforestation rates removed a crucial obstacle to a more pro-active position by these interests.

To summarize, mainly REDD, but also to some extent environmental pressures from foreign soya and beef markets, were influences going through the market pathway that helped changing coalitional politics linked to climate change in Brazil. REDD essentially transformed polluter interests in the Amazon region towards becoming helper interests seeing large potential profits in selling emission reductions related to avoided deforestation.

\subsection{The Big Companies: From Indifferent Polluters to Drivers for a New Position through Border Taxes}

With the election of Obama in 2008, US climate policy seemed to regain its momentum. The idea to impose "border taxes" on imports from countries without emission regulations was an important part of discussions in the United States. With the passing of the Waxman-Markey Bill on climate change by the House of Representatives in June 2009, this appeared as a credible threat for Brazilian business interests. Although ultimately failing to gain the necessary support from the US Senate, the bill caused alarm among Brazilian exporters, in particular Brazilian industrial exporters, who are crucially dependent on the US market [37]. The bill contributed to long-standing concerns among Brazilian industrialists and exporters over the damage from the country's negative reputation in US and European markets inflicted by high levels of Amazonian deforestation [38].

In the words of Hochstetler and Viola [1], the US process "galvanized a proactive response" by Brazilian industries and agribusiness and led to a series of initiatives by Brazilian industries and agribusiness in the early autumn of 2009. The most famous e of these initiatives was the "Open Letter" (Carta Aberta) from 22 of the biggest Brazilian companies led by the very large Brazilian iron ore exporter, Vale. The letter urged major changes of the Brazilian position. It was presented at a São Paulo conference on climate change in August 2009, in which the chief negotiator of the Itamaraty, 
Figueiredo, also participated [39]. There were also synergies with REDD related influences in this initiative. Environmental activists who were crucial for the parallel Amazon initiatives, like Virigilio Viana and Adalberto Verissimo from the important Belém-based NGO IMAZON, participated in promoting this initiative together with the São Paulo-based corporate social responsibility NGO Instituto Ethos.

Just a few days later, in early September, the Climate Alliance, an initiative formed by 14 organizations for companies involved in planted forests, bioenergy and agribusiness, published a position paper demanding commitments by Brazil, explicitly mentioning concerns for the threat of border taxes [40]. The companies behind this position paper also included what we in accordance with Sprinz and Weiss [8] term helper interests, namely the biofuel sector, which will be discussed more thoroughly below.

The Carta Aberta, the Climate Alliance and other initiatives [41] also demonstrated the synergies between international drivers for a new position. Business opportunities related to tropical forest carbon offsets and REDD were mentioned in many of the background documents, and discussions in processes that appear to have been triggered by the threat from the Waxman-Markey Act. Moreover, as we saw above, key figures behind the REDD-related processes were also drivers for this process.

To summarize, we see that the threat of US border taxes was an international market influence that clearly contributed to changing the position of industrial polluter interests from being rather negligent bystanders to Brazilian climate diplomacy towards becoming proponents of a change in the position.

\subsection{New helper Interests: New Energy Markets and the Rise of the Biofuels Sector}

The "climate alliance" also included a new set of helper interests, namely the booming biofuels industry. In Brazil, this industry came out of efforts to curb Brazil's oil dependence through subsidies to domestic bioethanol production following the first OPEC oil shock in 1973. After a bumpy trajectory for the bioethanol industry during the 1980s and 1990s, the extension of tax breaks to also include flex fuel vehicles able to run on various mixes of gasoline and ethanol finally led to a surge of production from 2003 [42]. Most of this expansion has taken place in the state of Säo Paulo. Here, production expansion has been accompanied by important technological improvements and intensive R\&D [42]. Besides being an integral part of Brazilian energy policies, Brazilian bioethanol production attracted increased attention as a climate mitigation option also internationally in the second half of the 2000s. According to João Capobianco, Secretary of Biodiversity at the MMA 2003-2007, the bioethanol producers' association UNICA (União da Indústria de Cana-de-Açúcar) became active as a proponent of a more flexible Brazilian position as early as 2006 [43]. The organization actively supported Brazil's opening to negotiations over rewards for avoided deforestation, in addition to involving itself in pushing for commitments by Brazil as member of the Climate Alliance in 2009. In 2008, the organization also came out in favor of a domestic emission trading market in Brazil and expressed enthusiasm for an international market for carbon offsets [44]. UNICA was, as noted above, also concerned with the problems facing bioethanol exporters in global markets associated with Brazil's negative reputation on Amazonian deforestation [38]. Thus, a set of mutually reinforcing market influences pushed Brazilian bioethanol producers towards becoming important new helper interests. 


\section{REDD, the Bali Agreement and Changes in the Governmental Authority Structure on Climate Change}

The outlook of the domestic coalition resisting changes of Brazil's position on commitments and forests in the negotiations was initially well matched with the preferences of the agencies that made up the governmental authority structure defining the country's position in the negotiations. At the center of this authority structure was the powerful Itamaraty, whose perspective on cooperation with the North in many issues areas (trade, environment) was largely similar to the G77 and its perception of an unbridgeable North-South conflict. This perspective had been galvanized during by mounting conflicts with the US over trade, patents and debt issues during the 1980s [19,45]. Although softened by the transition to democracy, a more assertive civil society, as well as growing transnational pressures, Vieira [46] notes that many of the Itamaraty's traditional concerns over national sovereignty in the Amazon and its conservative position on commitments by developing countries survived quite intact into the 2000s. Besides the Itamaraty, the MCT has had a role as a scientific advisor in the climate negotiations from the beginning of the UNFCCC negotiations. This ministry has traditionally been closely aligned with the Itamaraty [20].

The Ministry of the Environment, traditionally charged with dealing with deforestation and, thus, responsible for regulating the bulk of Brazil's emissions, was for a long time peripheral to decision-making on the Brazilian position. The Ministry held the position as vice-chair of the Interministerial Commission for Climate Change (CIMGC in Portuguese) — created in 1999 and chaired by the MCT) — c but funding problems, problems with staff quality and high personnel turnover provided the MMA with little capacity to use this commission as a platform for influencing Brazil's position [43]. Moreover, at that time, there was no clear aim by the ministry to change the Brazilian position, even though Vieira [20] notes a willingness by the MMA to accept emission targets and foreign funding to deforestation reduction in the Amazon that set it apart from the views of the Itamaraty.

However, this lack of involvement by the MMA in the bargaining over the position was certainly also connected to an important international factor; namely, the generally lacking attention to the issue of tropical deforestation and domestic action by developing countries in the UNFCCC negotiations and the international debate on climate change. Thus, the absence of international rules and norms related to domestic action in Brazil as a Non-Annex 1 country, and its main source of greenhouse gas emissions actually helped to marginalize the MMA in governmental decision-making on the issue of climate change.

When tropical deforestation assumed greater importance on the international climate policy agenda after the breakthrough at COP-9 and the formation of the Coalition of Rainforest Nations within the UNFCCC process in 2005, this opened a much wider space for the-with its strong competencies on deforestation - to involve itself in governmental discussions over the position. Domestic developments reinforced the ability of the MMA to exploit this new space. More stable funding and recruitment improved the ministry's capacities [43]. Complementing the increasingly favorable "fit" between MMA competencies and the emerging focus on deforestation in the UNFCCC negotiations, as well as better financing, the Ministry increasingly came out as a skillful negotiator in the process of intra-governmental bargaining. The new Minister, Marina Silva, and her closest associates had already 
started discussions on Brazil's climate policy and the issue of deforestation with NGOs, academics and people from the private sector in 2003, and these discussions developed gradually through 2004 [43]. Following this, there were also discussions with the MCT and the Itamaraty in which these ministries started to accept the importance of deforestation for emissions. As noted by Capobianco, Secretary for Biodiversity and later Executive Secretary at the MMA and deeply involved in these discussions [43]:

"When we won the fight inside the government in terms of the relationship between emissions and forests, Brazil started to be one of the most important and interesting actors in the negotiations."

The growing linkages between climate change and deforestation both at home and abroad provided a justification for increasing MMA participation in Brazil's delegation to the COPs. Before 2003, the MMA had only sent junior staff to these events. However, in 2003, the Executive Secretary of the MMA participated and during the following COPs, the Minister of the Environment Marina Silva always participated and acted as leader of the delegation on several occasions. Other top staff also became involved. MMA's Capobianco presented Brazil's proposal for a funds-based solution for reduced tropical deforestation in a technical workshop promoted by the Food and Agriculture Organization (FAO) at Rome in September, 2006, and at COP-12 in Nairobi. Capobianco's role in these events also demonstrates to what extent the ascent of forest issues on the UNFCCC negotiation agenda favored MMA involvement in intra-governmental bargaining over the position. More purely domestic factors and achievements were also of key importance. The declining deforestation rate, which was seen as strongly connected to more effective anti-deforestation programs led by the MMA [1], strengthened the hand of the MMA in intra-governmental discussions.

The next move by the MMA was to change one of its old secretariats into the Secretariat for Climate Change and Environmental Quality with a separate Department for Climate Change in early 2007, thus challenging the scientific role of the MCT. This was a deliberate move to insert the MMA more strongly into government discussions on climate change both domestically and internationally [43]. The first Secretary for Climate Change was Thelma Krug, a highly respected Brazilian climate scientist.

In September 2007, President Lula initiated work with a domestic climate plan for Brazil. The plan was to be prepared by a new Interministerial Committee for Climate Change (CIM) consisting of 16 ministries and led by the President's office (Casa Civil). More important for the intra-governmental struggles over Brazil's position, the MMA was given the task of heading the executive committee charged with developing the climate plan. The idea of a fully fledged domestic climate policy in a non-Annex 1 country like Brazil was obviously assisted by the pathway of non-binding norms within the climate regime, namely the acceptance of voluntary mitigation efforts (Nationally Appropriate Mitigation Action or "NAMA"s) also by developing countries at COP-13 in Bali.

In turn, these domestic intra-governmental changes facilitated by international norm changes became a platform for increased MMA mobilization to change Brazil's positions in the following years [47]. Key successes here were the ability to push through Brazilian acceptance of the two degree target, against skepticism by the Itamaraty and the MCT [48] in mid-2009 and the publishing of a Brazilian emission inventory by the Secretariat for Climate Change at the MMA in September 2009, removing a key obstacle to the establishment of Brazilian emission targets and challenging the role of 
the MCT. At this time, the MMA increasingly became a hub for climate policy related activity, not only within the government, but also in society. Carlos Minc, who took over as Minister for the Environment after Marina Silva left office in May 2008, demonstrated a superior ability to use MMA's new role as a key ministry for climate policy to assist many of the changes in coalitional politics that took place in 2008-2009. In turn, Minc could bring the shifts of preferences among societal actors as assets into intra-governmental discussions.

Emphasizing the importance of previous changes in government authority structures for the shift of the Brazilian position, the final discussions that led up to the announcement of Brazilian "voluntary targets" before COP-15 took place in the Interministerial Commission on Climate Change, the very same body established in 2007 to deal with domestic climate policy. As noted, the MMA had a key position in this commission. In the final discussions, MMA representatives again demonstrated their skills in the game of bureaucratic politics by managing to convince ministries like the Ministry of Agriculture and the Ministry of the Economy about the potential positive effects of a voluntary target [49]. The pro-active positions chosen by these ministries in the final meetings were in turn facilitated by the new willingness among agricultural and industrial business interests to actually support mitigation commitments by Brazil. It was also important that the resistance of the MCT started to unravel, as conflicts between its representatives started to emerge [50].

Lula's decision to listen to this coalition of ministries (and behind them, a new coalition of societal interests) instead of giving in to the skepticism of the Itamaraty demonstrated the MMA's ability to fully exploit the changed institutional setting for Brazilian climate policy at this point. More fundamentally, the MMA's success in the game of bureaucratic politics was assisted by changes of international non-binding norms, namely the opening for, including avoided deforestation in the UNFCCC negotiations after 2005 and the opening for domestic action by developing countries in the wake of COP-13 at Bali in 2007. Together with the country's performance in actually cutting deforestation, these international norm-changes favored a change of the governmental authority structure on the climate policy issue; namely, the inclusion of the MMA in domestic bargaining over domestic climate policy and Brazil's positions in the negotiations.

However, it is important to note that success at this point was not the end of a linear process of uniform change. Indeed, as noted by Vieira [46], the MMA's struggle was marred with confrontations with more nationalistic and developmentalist factions of the ruling party and the bureaucracy, which were important for the Lula government's economic development projects. In 2008, this conflict reached a climax when the Minister for the Environment, Marina Silva, left office in protest against the influence of these forces. However, Silva's replacement Carlos Minc turned out to be even better in the game of bureaucratic politics in the fluent climate policy context prevailing at that time.

Thus, to summarize, the argument brought forward when it comes to international influences on the governmental authority structure is the following: the rise of issues related to deforestation and climate change on the UNFCCC agenda made the MMA's competencies on deforestation much more relevant for Brazilian climate policy. This opened a policy window for skillful bargaining and maneuvering by the MMA, which systematically managed to increase its influence in intra-governmental negotiations over the position. Successful mobilization of societal actors and exploitation of preference changes by societal groups by the MMA certainly contributed to this success, as did the Ministry's 
ability to contribute to a declining deforestation rate after 2005 by launching more effective anti-deforestation programs.

\section{Conclusion: The Second Image Reversed and Domestic Climate Politics}

Above, I have demonstrated how a set of impulses from Brazil's international environment - namely the increased UNFCCC focus on efforts to curb deforestation, the following prospect of payments related to avoided deforestation, the threat of border taxes in the US, the rise of a global, climate related market for the biofuels sector and the decision to open for domestic action by developing countries at Bali-contributed to the changes in Brazil's position in 2009. This happened both because influences through the market pathway transformed the domestic societal coalitions on climate change and because new norms on the role of deforestation and domestic climate policy also for developing countries in the UNFCCC negotiations legitimized a stronger role for the MMA in intra-governmental bargaining over the position. In this new and more favorable context, the skillful maneuvering by the MMA that both benefited from and contributed to the mobilization of reform-minded societal actors ultimately led to the changes of Brazil's position on commitments in November 2009. Thus, Bernstein and Cashore's [11] observation that various pathways for influences from the international to the domestic level can act synergistically is well illustrated by this process. Moreover, the blurring of the national/international divide discussed by Bernstein and Cashore [11] is highly visible. The Amazon state initiatives for a change in the position were for example strongly supported by transnational forums, like the Katoomba process, and by the parallel involvement of US researchers in many forest initiatives [25]. There were also examples of external influences going through the "direct influence" pathway. The establishment of the Amazon Fund in 2008 alongside negotiations between Norway and Brazil was spurred by the prospect for generous Norwegian funding. Similar influences came from the US. In 2008 in Los Angeles, the states of California, Illinois and Wisconsin signed memorandum of understandings (MoUs) with Amazonas, Amapá and Mato Grosso (and two Indonesian states) with a clear aim of integrating US state efforts to cut emissions with financing of reduced deforestation in the Amazon region. While both actions facilitated changes of Brazilian authority structures linked to climate policy in general - the establishment of the Amazon Fund under the auspices of the Brazilian Development Bank (BNDES) and state forums for climate change in the Amazon region - the main effects of these more direct interventions were probably to provide more credibility to the idea of a profitable global market for carbon offsets in the Brazilian Amazon, illustrating the synergy between different pathways. However, referring back to Berstein and Cashore [11], the difficulty of sorting initiatives like these in a simple manner under different "pathways" also indicates the complexity of international-domestic interactions in international environmental affairs.

Moreover, as noted in the introduction, a comprehensive explanation of the changes in Brazil's position relies on a conjuncture of international and domestic factors. Above, I have highlighted the MMA's skills in the game of bureaucratic politics as an important domestic factor contributing to the change. Moreover, the startling decline of the deforestation rate in the wake of more effective anti-deforestation programs by the MMA since 2005, a factor that is given prime importance by Hochstetler and Viola [1], made commitments much less threatening for Brazilian interests. The same goes for Hochstetler and Viola's [1] attention to the importance of electoral politics - both the 
long-standing concerns over climate change in the electorate and Marina Silva's decision to run for president in rivalry with Lula's candidate in the autumn of 2009-provided a favorable domestic context for change. Interpreting the influence of these developments to some extent this depends on the angle chosen. Based on a "second image reversed" approach, one can also say that these domestic developments provided a favorable context for international factors to have effect on position development.

A domestic approach and a "second image reversed" approach could also end up with slightly different interpretations of developments after the change in 2009. On the one hand, domestic agribusiness interests have mobilized successfully against some of the environmental restrictions in the Forest Code, demonstrating the inherent tensions between environmentalism and developmentalist interests in agribusiness vividly outlined by Vieira [46]. On the other hand, the strength of this developmentalist block and the apparent waning of a powerful pro-environmental coalition are both linked to the international context. While food and commodity prices have offered unique opportunities for profit for the Brazilian agribusiness sector, a sluggish international climate process following the disappointment in Copenhagen has provided little external pressure for a sustainment of the environmentalist offensive that characterized Brazil (and the international system) in the years before COP-15. The potential domestic pressures from the expected increases of Brazilian oil production will not make it easier to rejuvenate this climate policy offensive [51].

While this paper offers a more internationally grounded explanation of domestic events in Brazil's climate policy, supplementing Hochstetler and Viola's more domestically oriented contribution, it is also important to point out that more purely international (or third level) events may have imposed limits on the changes in the Brazilian position. Hochstetler and Viola [6] point to how Brazil's alliance with China, India and South Africa in the BASIC (Brazil, South Africa, India and China) group from 2009 may have blocked the change of positions in Brazil to also involve a broader call for commitments by developing countries. Hurrell and Sengupta [52] note how the difficulties of the "emerging powers" in finding a stable and secure position in the international system may reinforce the constraints of constellations like the BASIC group on its members.

However, the existence of these second image and third image dynamics introduced to qualify my argument above does not preclude the core idea of this paper, namely that analyzes inspired by the second image reversed approach may provide important contributions to our understanding of the dynamics of international climate policy. The weak hopes for a binding global agreement on climate change forces us to explore how and through what pathways various non-binding norms and economic incentives can influence domestic climate policy. At the same time, it can be argued that the emergence of a vast "regime complex" on climate change [53], instead of a single, binding agreement is an open invitation to explore the effects of the different components of this "complex" on domestic politics. These observations are particularly relevant for developing countries, which are not yet included into any binding agreement on climate change.

\section{Acknowledgements}

The author would like to thank Eduardo Viola at the University of Brasilía for field work assistance, encouragement and comments. Thanks to two anonymous reviewers for essential comments and to Donald Sawyer (Institute for Society, Population and Nature, Brasilía) and Olav Schram Stokke 
(Fridtjof Nansens Institute, Bærum) for valuable advice. Support from The Norwegian Research Council through grant no. 196090 (QUANTIFY) and travel support from NORAD (The Norwegian Agency for Development Cooperation) are gratefully acknowledged.

\section{References and notes}

1. Hochstetler, K.; Viola, E. Brazil and the politics of climate change: beyond the global commons. Environ. Polit. 2011, 21, 753-771.

2. Ikenberry, J. Liberal Leviathan: The Origins, Crisis, and Transformation of the American World Order; Princeton University Press: Princeton, NJ, USA, 2011.

3. Vargas, E. A Mudança do Clima na Perspectiva do Brasil. Interesse Nacional. 2008, 1, 9-14.

4. Gourevitch, P. The Second Image Reversed. Int. Organ. 1978, 32, 881-912.

5. Krasner, S.D. Changing state structures: Outside in. Proc. Natl. Acad. Sci. USA 2011, 108, 21302-21307.

6. Hochstetler, K.; Viola, E. Brazil and the Multiscalar Politics of Climate Change. In Colorado Conference on Earth Systems Governance, Colorado State University, Fort Collins, Colorado. Available online: http://cc2011.earthsystemgovernance.org/abstracts.html. (accessed on 27 February 2013).

7. Ragin, C. The Comparative Method. Moving beyond Qualitative and Quantitative Methods; University of California Press: Los Angeles, CA, USA, 1987.

8. Sprinz, D.F.; WeIß, M. Domestic Politics and Global Climate Policy. In International Relations and Global Climate Change; Lutherbacher, U., Sprinz, D., Eds.; The MIT Press: Cambridge, MA, USA, 2001; pp. 67-94.

9. Kasa, S.; Gullberg, A.T.; Heggelund, G. The Group of 77 in the international climate negotiations: recent developments and future directions. Int. Environ. Agreem. P. 2008, 8, 113-127.

10. Young, O.R. Regime Effectiveness: Taking Stock. In The effectiveness of International Environmental Regimes: Causal Connections and Behavioral Mechanisms; Young, O.R., Ed.; The MIT Press: Cambridge, MA, USA, 1999; pp. 1-32.

11. Bernstein, S.; Cashore, B. Complex global governance and domestic policies: Four pathways of influence. Int. Aff. 2012, 88, 585-604.

12. Andonova, L.B. The climate regime and domestic politics: the case of Russia. Camb. Rev. Int. Aff. 2008, 21, 483-504.

13. Costa, O. Is climate change changing the EU? The second image reversed in climate politics. Camb. Rev. Int. Aff. 2008, 21, 527-544.

14. Stevenson, H. India and international norms of climate governance: a constructivist analysis of normative congruence building. Rev. Int. Stud. 2011, 37, 997-1019.

15. Henry, L.A.; Sundstrom, L.M. Russia's Climate Policy: International Bargaining and Domestic Modernisation. Europe-Asia Stud. 2012, 64, 1297-1322.

16. Takao, Y. The transformation of Japan's environmental policy. Environ. Polit. 2012, 21, 772-790.

17. Litfin, K.T. Advocacy Coalitions Along the Domestic-Foreign Frontier: Globalization and Canadian Climate Change Policy. Policy Stud. J. 2005, 28, 236-252.

18. Hurrell, A. The politics of Amazonian deforestation. J. Lat. Am. Stud. 1991, 23, 197-215. 
19. Miyamoto, S. Diplomacia e militarismo: o Projeto Calha Norte ea ocupação do espaço amazônico (in Portuguese). Revista Brasileira de Ciência Política 1989, 1, 145-163.

20. Kasa, S. Democratization and the Issue of Climate Change in Brazil 1987-1994; Working Paper 6; Center for International Climate and Environmental Research: Oslo, Norway, 1995.

21. Cepaluni, G.; Vigevani, T.; Philippe, C. Brazilian Foreign Policy in Changing Times: The Quest for Autonomy from Sarney to Lula; Lexington Books: Plymouth, UK, 2009.

22. Persson, M.; Azar, C. Brazil Beyond Kyoto-Prospects and Problems in Handling Tropical Deforestation in a Second Commitment Period; Naturvårdsverket: Stockholm, Sweden, 2004.

23. Johnson, K. Brazil and the politics of the climate change negotiations. J. Env. Develop. 2001, 10, 178-206.

24. Viola, E. O regime internacional de mudança climática e o Brasil (in Portuguese). Revista Brasileira de Ciências Sociais 2002, 17, 25-46.

25. Santilli, M.; Moutinho, P.; Schwartzman, S.; Nepstad, P.; Curran, L.; Nobre, C. Tropical Deforestation and the Kyoto Protocol: A new proposal Tropical Deforestation and the Kyoto Protocol: A new proposal. Carbon 2003, TS-RIS.

26. Interview with Paulo Moutinho, IPAM, May 2010.

27. Center for Climate and Energy Solutions. COP 12 Report. Available online: http://www.c2es.org/ international/negotiations/cop-12/summary/ (accessed on 27 February 2013).

28. Interview with former Secretaries for Climate Change in the MMA, Suzana Khan Ribeiro and Branca Americano, 2010.

29. Hochstetler, K.; Viola, E. Brazil and the Multiscalar Politics of Climate Change. Paper presented at the 2011 Colorado Conference on Earth Systems Governance, Colorado State University, Fort Collins, CO, USA, 17-20 May 2011.

30. Fearnside, P.M.; Barbosa, R.I. Avoided deforestation in Amazonia as a global warming mitigation measure: The case of Mato Grosso. Glob. Warn. Int. Ctr. M. 2003, 15, 352-361.

31. Kaimowitz, D.; Mertens, B.; Wunder, S. Hamburger Connection Fuels Amazon Destruction; Center for International Forest Research: Bogor, Indonesia, 2004.

32. Greenpeace. Eating up the Amazon; Greenpeace International: Amsterdam, The Netherlands, 2006.

33. Sawyer, D. Climate change, biofuels and eco-social impacts in the Brazilian Amazon and Cerrado. Philos. T. R. Soc. B 2008, 363, 1747-1752.

34. Barone, E.; Ramankutty, N.; Hyman, G.; Coomes, O.T. The role of pasture and soybean in deforestation of the Brazilian Amazon. Environ. Res. Lett. 2010, 5, 1-9.

35. KATOOMBA. Katoomba XIV: Avoiding Deforestation in the Amazon through PES Markets. Available online: http://www.katoombagroup.org/ katoomba/event_details.php?id=26/ (access on 27 October 2012).

36. Amazônia pede a Lula nova política para floresta (in Portuguese). O Estado de São Paulo, 1 July 2009.

37. See the comment of the Minister of Development, Industry and Foreign Trade, Miguel Jorge: "Novo risco às exportações brasileiras", Folha de Sao Paulo, 14 September 2009. Own interview with Eduardo Viola, advisor for the campaign "Empresas pelo Clima" in 2011.

38. Interview with Luiz Fernando Amaral, environmental advisor, UNICA, May 2011. 
39. Homepage of Instituto Ethos. Available online: http://www1.ethos.org.br/EthosWeb/ pt/2829/servicos_do_portal/noticias/itens/e_hora_de_tomar_atitudes_.aspx/ (accessed on 27 February 2013).

40. UNICA's Homepage. Available online: http://english.unica.com.br/noticias/show.asp? nwsCode=\%7B5E846923-01FA-4099-B54E-D969BC3756A3\%7D/ (accessed on 27 February 2013).

41. Viola, E. A política climática global e o Brasil, 2005-2010. Tempo do Mundo 2010, 1, 81-117.

42. Hira, A.; de Oliveira, L.G. No substitute for oil? How Brazil developed its ethanol industry. Energ. Policy 2009, 37, 2450-2456.

43. Interview with João Capobianco, May 2011.

44. Nelson, A. Climate Change and Biofuels; Woodrow Wilson International Center for Scholars: Washington, DC, USA, 2010.

45. Hurrell, A. Brazil and the new global order. Curr. Hist. 2010, 109, 60-68.

46. Vieira, M.A. Brazilian Foreign Policy in the Context of Global Climate Norms. Foreign Policy Analysis 2012, doi:10.1111/j.1743-8594.2012.00191.x.

47. In interviews with Tasso Azevedo and Branca Americano, May 2010, it emerged that the push for a change in positions was coordinated by a small group of dedicated employees within the MMA and in its subordinated agencies (Azevedo was head of the Brazilian Forest Service in these days).

48. Azevedo, T. Reflexoes telegraficas sobre a COP 15. Unpublished work.

49. While the Ministry of Economy was enthusiastic about the potentials for a domestic emission trading market, representatives of the Ministry of Agriculture saw potentials for Brazil in less emission-intensive agriculture. Interviews with Tasso Azevedo and Branca Americano, May 2010.

50. Abranches, S. Copenhague: Antes e Ddepois; Civilização Brasileira: Rio de Janeiro, Brasil, 2011.

51. Petherick, A. The Muddled Progressive. Nat. Clim. Chan. 2013, 3, 7-9.

52. Hurrell, A.; Sengupta, S. Emerging powers, North-South relations and global climate politics. Int. Aff. 2012, 88, 463-484.

53. Keohane, R.O.; Victor, D.G. The regime complex for climate change. Perspectives Politics 2011, 9, 7-23.

(C) 2013 by the authors; licensee MDPI, Basel, Switzerland. This article is an open access article distributed under the terms and conditions of the Creative Commons Attribution license (http://creativecommons.org/licenses/by/3.0/). 